\title{
Waqf as a Social Entrepreneurship Model in Islam
}

\author{
Dr Habibollah Salarzehi \\ Faculty of Management, University of Sistan and Baluchestan, Iran \\ block B-11-10, JLN Tanming Permai 1, juta mines condominium \\ Seri Kembangan, 43300, serdang, kulalampur, Malysia
}

Hamed Armesh

Faculty of Management, Multi Media Universiti, Malaysia

E-mail: hamed_dba@yahoo.com

Davoud Nikbin

School of Management, Universiti Sains, Malaysia

\begin{abstract}
By the end of twentieth century and beginning of the third millenary, social entrepreneurship emerging has been found as a completion part of commercial entrepreneurship and governmental entrepreneurship. In religious schools, especially inspired school of Islam, noble human values and moral teaching of cooperation, Support a suitable depth to dispose of the social entrepreneurship and goodwill action. Tradition of philanthropically alms, Ehsan and charity are going to be dealt with in this article. Rich culture of Islam Inspired by the values of the friendship, cooperation and voluntary participation in the various spiritual and material activities Self-sacrifice and personal property and allocation it to public affairs and social welfare under the name of Waqf, specificity unique Islamic almshouses or social entrepreneurship in Islamic countries. The current article with micro antipathetic descriptive and analytical approach, dedicated to explain the Islamic and sustainable social entrepreneurship model for development and social welfare programs.
\end{abstract}

Keywords: Social entrepreneurship, Good will, Social development

\section{Introduction}

Experience has shown that governments would not be able to provide public interests, also are not able to get the developmental goals. And they highly need to get the best use of commercial sector capacity in production of goods and services that in effect caused the spread of the economic development in the developed countries and fields of economic prosperity, employment and stable relative welfare of Citizens. The more expansion in private sector's activity and share, the more Welfare, and comprehensive development in the society will be predictable. The private sector in development literature is considered as a motivator engine of economy in society and one of the reasons for failure of the developing and Islamic countries in the realization of developmental goals, weak economic structure and the weak presence of the private sector and the comparatively high interference of government in economic system. Despite of active presence of the private sector in the form of commercial firms, proofs show that the market experience has been unsuccessful in getting overcome on deprivation and in meeting the public interests as well; it is happening just because the private sector activities in the realm of the market is highly profit oriented and are based on the criteria of economic rationality and they are seeking for their own personal benefits. Therefore, social entrepreneurship within the Popular Participation frame work and organized groups of people and NGOs is the completing cycle in the light of the strategic government and the active private sector; and can bridging the gap between the government and market (Stevenson et al., 2006).

The Philosophy of the charity institutions and NGOs existence is using the capacity of public participation. Which are active for philanthropically purposes and are motivated by religious beliefs and they want to solve the social problems in different areas. As it's shown in figure (1), the government failure in eliminating the deprivation is because of the budget limitations and private sectors lack of desire in pursuing social issues and their profiteer nature, so it requires the participation of the civil capacity and social entrepreneurship to compensate the government and market failure. Social entrepreneurship in development literature that emerged in the shape of third path theory and NGOs has emphasis on voluntary participation by all society members to 
meet lower classes' claims and demands. The main character of entrepreneurship actions and social entrepreneurship is to do something with goodwill and philanthropically intentions in pursuing social goals (Weerawardena, 2006).

\section{Social entrepreneurship}

Entrepreneurial is derived from French literature in 17th and 18th centuries A. D. Entrepreneurship pointed out to those who have been looking for better ways to do works done, and with experiencing Economic development as a result. Entrepreneurs with optimum use of resources and limited facilities offered more, productivity and efficiency act that it has a remarkable and more exact value-added. In economic discourse Joseph Schum Peter, Commercial entrepreneurs are innovators who are pursuing economic goals (Dees et al., 2001). They always are in search for change, smart reaction to the changes and use the maximum benefit form changes. In entrepreneurship Literature, in addition to the commercial entrepreneurship which is more business and commerce oriented and taking the risk is their concern to achieve the profitability goals; social entrepreneurship is as a complementary to business entrepreneurship, have a special position in social development literature. The nature of Social entrepreneurship is the cooperative activities such as the philanthropically activities alms, charity, benevolence, and sense of responsibility for the problems of the vulnerable and deprived classes of the society. The necessity for social entrepreneurship in modern society, that is revealed today, is deadlock of capitalist system which has emphasis on personal profitability and ignoring the rights and needs of vulnerable classes, caused the added severity of poverty and deprivation and increase the gap between classes in the society.

Government and commercial institutions' failure to solve the social issues has been declared that, today society for confrontation with complex social issues needs social entrepreneurship and creativity. Social entrepreneurship includes innovative programs to improve livelihood that who have no business of financial power. And in using of social services opportunity are faced to the limitations. This group of benevolent entrepreneurs act, based on the values and value mission that believe in them, to initiative and innovate social security to satisfy the needs of the society. They have done it because of relations and social ties to almshouses and solving problems (Gliedt and Parker, 2007). The essence of social entrepreneurship is an innovative voluntarily and the kind of friendship with a combination of good will. These kinds of entrepreneurs give services to human being aim to get an inner satisfaction. Social entrepreneurship is a process which in, individuals and groups and social sectors working voluntary in order to produce value by using remained social assets and opportunities. ; In societies people gather together and get along to have cooperation and bilateral cooperation in order to solve social issues., social capital on the base of trust has been created to that extant in which they can create long lasting capacity for dealing with issues (Miri, 2006).

Social entrepreneurship is the innovation for the problems and social issues. Social entrepreneurs normally use the innovative measures to create a mechanism of social security and mobilize resources to deal with social issues. Social entrepreneurship seeks to identify the social and society needs thus, they have encountered ups and downs (Alvord and Brown, 2004). One example of the successful social entrepreneurship is a Sekem, a nonprofits organization that have established in Egypt. The ancient name of Egypt means solar energy that based on of native tradition and Islamic teachings in 1977 later this institute had been turned into a multi-purpose company and its income would use for the adult education, health and treatment of the vulnerable. Also in this institute a lot of efforts had been done to gain the trust and support of entrepreneurship to advance plans for eliminating poverty. This institute had administered to national awards and international humanitarian measures for eliminating poverty (Seelos and Johanna, 2005)

\section{Social entrepreneurship in Islam}

Experimental evidence confirms that good actions are rooted from people's, beliefs and social culture and social believes of every nation's are the essence of personality and communities in trends of friendship and voluntary behaviour .one study about religion's effects on charity activities in Canada, they confirmed that religious belief are influential for expansion of charity and voluntary. Based on this findings, Canadian citizens with strong religious beliefs, in comparison to others had more participations in charity activities (Berger, 2006). Bekker et al., (2007) in a field study about effective factors in good activities and friendship found out that the religious values and morale behaviour are so important (Bekkers et al., 2007). Wang and Grady (2008) also in the assessment relations between voluntary action, Social capital and charitable contributions, found that religious beliefs is one of factors that determine the voluntary action and increase in charitable and humanitarian assistance. Religious citizens have believed in having more incline to help vulnerable and the disabled people (Wang and Graddy, 2008).

In a comparative study, different religions were compared in regard to charity activities that investigated Islam 
school in compare to many religious schools paying more attention to the activities of the kind of friendship and charity (Salamon and Anheier, 1997). Values and common religious symbols in Islamic culture such as alms, pay attention to poor and the deprived, offerings, devotion, Ehsan and being kind with slaves, friendship, cooperation and participation and dedicated to property goals for charity have been shown that capabilities of the vast social entrepreneurship in Islam. Dr. Bellin says something about devoting in Islam that: "People always have been invited to charity and Ehsan in the Quran and we cant find a chapter in Quran that does not say about budding life or property in the way of God (Bandarchi, 1998). Verses of Quran and many of traditions, has inspired the paradise to Muslims for humanitarian measures and observance. In addition, God has created human kind and asked them to be useful to each other. The tradition of the Prophet Mohammad: "God love the people whom help the poor and needy mankind".

In one of the traditions of his holiness that named Qodsi also paying attention to people needs has been emphasized. In this tradition: "God will only accept the Praying of that Prayers whom live moderately on and do not persecute animals and other creatures of God, don't persisted the sin and call God with the mourning are kind with beggars, eroding love to the poor, passengers remained in the way, widows and classes of damaged". Therefore, within the framework of Islam belief, friendly tradition of charity, and significant action have had, mercy and kindness for assisting (Krafess, 2005)

Pure Islam is guideline for, peace, prosperity, good will and social welfare. In the Tradition of the Prophet Mohammad comes: "The first will enter of heaven gates are assistant" (Alioune, 2007). The principle of social justice in Islam in accordance with GOD ordered in Quran Also approved this point that the poor people and needy have same share from wealth and property rights; because within the framework of Islamic law all things belong to the Essence of God. And whatever from his wealth and property that gives some should, forgive and help others. In the Islamic texts it has been emphasized. That God has hosted reformer slaves and charity that is not only prayer, but are pioneers in the good works (Sami, 2006).

\subsection{Islam; highly appreciated base for Waqf and sustainable social entrepreneurship}

Waqf, have had a long record in culture and civilization of the human and nations history. Instances of it can be in Egypt's pharaohs. Pharaohs had old Egypt, allocated property and lands for monks in old Egypt. And in ancient Greek civilization, there are signs of library Waqf and educational centres. Before Islam, Waqf can be seen to instances and charity activities in divine Prophets life and traditions. Abraham were one of the first founders of devoted, during his life was founded charity and the relief efforts. The main point is that the well-meaning and devoted to assisting with their property in the form of Waqf, to leave the ownership of that property forever and spent it to public works (Bremer, 2004).

Waqf as a base thorough which the continuance of alms is possible have been usual in ancient between different nations, but in Islam, because of emphasize in Quran and traditions to help the weak and poor people it has made charity and devoting more important. Although in ancient religions and between the United Nations the devote Property had been usual, but Waqf in Islam having a special situation and has emphasizes in religious teachings to go that in order to attract God's satisfaction (Anjavinejad and Eami, 2005) Islamic civilization have had a considerable effect on the valuation of Waqf and lots of non-Muslim countries have obeyed the Waqf culture in Islam and have taken a long step in the field of property dedicated to goals for humanitarian and development. At the moment, in the North America, many of religious and charity foundation are belonged to properties benefits. And thousands charity foundations are just active in America. Oxford University almost has been introduced as model of Waqf based on Islamic foundation dedicated. The record of finance and properties' Waqf for the development of educational centres for the first time in the world has been in Islam. Al-Azhar Islamic University in Egypt also is a successful models of University in world that is based on the benefits investment and it has been allocated major parts of the financial sources of university to educational centres, Waqf in western countries is known as a Islamic custodianship or piety foundation that Muslim citizens by allocating property in social welfare programs and support of their vulnerable religious obligations to attract attention and consent of God Almighty. This embodied action and forgiveness of property shows the capacity of the Islamic faith and belief That Muslims with the aim of divine revelation and of God's satisfaction doing this observance action and allocating a part of their properties for others welfare (Kuran, 2001).

In Juratory Waqf means keeping out, imprisonment and forbid. Wag is imprisonment of possessions and to prevent the transfer it to another (Astan Ghods razavi, 2008) in Islam Waqf means keeping property and allocate it to solidify good goals. Usually Waqf include Durable Goods and long lasting estates such as agriculture, commercial and residential, or Waqf of libraries, agricultural machinery, livestock, stock, savings and cash. Waqf means dose not use of personal property and allocated benefit for determined goals. Ownership of 
dedicated property cannot be transferred to another person; except under certain conditions that could be upturn and benefits form can to be allocated to intended goals. Major differences between Waqf with alms and bounties in traditions and Islamic texts is that alms and bounties have been introduced as a good overpowered activity (9) While alms and Waqf in Islamic culture is a voluntarily charity activities (10) Based on the feelings of friendship. The difference between charity and Waqf is that charity usually is normal action and includes part charitable contribution, While Waqf is voluntary action that the owners of the capital, dedicating permanently part of their personal property for charity activities Therefore, Waqf (11) is kind of permanent and continuous alms, Waqf similar to other activities is in the realm of voluntary charity. Applications goals and profits of Waqf can be spent on educational institutions, orphan home, utilization of mosques and other activities worsening public charity (Sadeq, 2002).

\subsection{Three types of Waqf in Islam}

1. Religious Waqf: The majority of mosques in the Islamic world is kind of religious Waqf that they have been founded by well-meaning. In addition the property has been allocated for mosques and religious schools are kind of endowments.

2. Philanthropic Waqf: in humanitarian Waqf, benefits are allocated to public for the support poor and also promote social activities. For instance the library, educational centres, health care, animals care, takes care of Environment, development activities of the green space, and roads are kind of benefits.

3. Family Waqf: the third kind of Waqf is pointed to Waqf from the parents to children and Heir. So that the extra income will be spent for poor people (Kahf, 2000)

Studies and evidences have been shown that Friendly use of Waqf and other embodied activities in Islamic countries are subjects of various Conversions and emphasis on its value in Islam has emphasized on, kind of friendship, feeling responsibility about life quality of poor and vulnerable citizens and moral and religious obligation to solve the problems of the vulnerable. Religious factors like a strong faith and virtue, individual personality factors, and gentle spirit and generosity and job base, the level of income, the level of education and social consciousness are components of determining the charity measures such as Waqf. All these will help to get the developmental programs and considerable part of strata and the poor people can use these opportunities and benefit of social services (Shakori, 2007)

Figure 2 shows the result of studies regarding the identification of good embodied such as tradition of Waqf. In the Islamic society, the pious believer citizens, treat Waqf and charity as a device for consent of god. And with regard to the strict instructions of God in the Quran and tradition of Prophet Based on the regeneration friendly tradition and help others, eagerly consume part of their property of their affairs for Muslims And filters the Possession that part of their property for always. In addition to the aspects of the belief; other important elements are such as no significant action, kind of character of men, in pursuit of perfection, seeking fame and pluralism measures and humanitarian activities not solidify. Belongingness and need to be respected and ultimately self-seeking are non-human material needs. And in comparison, the motivation of belonging, gaining status and ultimately self-seeking among the benevolent are more than others. Experimental findings have also confirmed that kind of friendship and no significant action is depending on income, education and employment base. The higher the people's income is the more benevolent opportunities will increase. Major benefices in Islamic countries have been established by rich people. Education level and employment are in parallel with the level of citizen's income which has influence on significant actions and in addition to these, understanding the conditions of vulnerable social groups and knowledge and obligations of social responsibility are also effective in the good will. Summary of the causes of the transition to charity activities and Waqf to the works and the results of these measures has been shown in Figure 2 (Sami, 2006; Krafess, 2005; Jennifer, 2004).

\section{Waqf and its effect on the development and social welfare}

In Islamic teachings, efforts to achieve legal property have been considered as kind of worship, mechanism of eliminating poverty and the distribution of wealth such as paying alms, paying attention to the poor and orphans feelings, Ehsan and charity with vulnerable strata and all the more important friendly Waqf tradition. It has been shown the capacity and strong support of Islamic culture to promote social development in Islamic societies. Experience of Waqf in Islamic countries has been shown that benefices can achieve the objectives connected with development of social role. For example, urban services, education, health and treatment are indexes of development. Developing of Waqf culture in the fields of education, health and social welfare have considerable influence on promoting social development (Sami, 2006). In Malaysia evidences have shown that the Waqf in addition to use its expenses in health and education fields there are many instances of use to participate in establishment of cooperative housing, industrial companies, libraries, laboratories and research centres and 
having a direct effect on the promotion of economic growth and gross domestic product of this country (Ariff, 1991).

Waqf is as an Islamic charity foundation for the realization of goals through the property and finance that allocated to legal foundation. In Islamic countries there are many projects that are operated through benefices and assets of the Waqf from well-meaning. The results of Waqf can be expressed to humanitarian projects, cultural, economic, health, education and training, and much other social welfare. For example Waqf of the spring water for public consumption, building houses for deprived, the place free place for an impecunious travellers, preserving bridges, organize the funeral of the dead who were poor, helping the handicapped, financing the marriage young people in need, and maintenance orphanage and the homes of the seniors' instances of use of Waqf property and assets. There are many instances of benefices use in the fields of health, treatment, education and training .For example hospitals and mobile medical rescue groups who are travelling village to village are managed through the property and assets of the Waqf (Krafess, 2005).

In many Islamic countries have been done many considerable parts of a development activities based on sources and dedicated assets (Sadeq, 2002).

1. Training courses such as primary schools and secondary schools and also established colleges and higher education centres (for example in Bangladesh more than 8000 of educational institution on the basis of Waqf have been established).

2. Building Houses and taking care of orphan centres which kept the children and people without shelter and give those living facilities and free education.

3. Almost the majority of the mosques in Bangladesh are as Cultural and public Centres offer social services to Muslims and about 120 thousand mosques have been established through Waqf and educational activities in the mosques would be presented for free. In addition in rural Bangladesh, mosques and Islamic teachings educational schools would be managed on the basis of benefices.

4. Clinics and health centres are examples of the charity activities based on sources of benefices. The Hamdard foundation based on herbal medicine in Karachi that is successful model using the capacity of aid and people's benefices. Also this clinic financially supported from the University of Karachi and relief aid workers in Pakistan, India and Bangladesh and give medical services at the disposal of the vulnerable.

5. Dedicated stores and commercial centres which are source of income opportunities and providing financial sources for public work and charity project.

6. Other sources such as finance and residential property, agricultural, stock companies and factories.

In addition to these, Waqf can be more effective in eliminating poverty programs and realizing comprehensive methods. In the past benefices had been used to construction and equipping the shrine, maintenance and established training centres and the fields of health and treatment, preparing food for poor, But now Waqf in addition cases can be use of drinking water supply for urban or rural areas, city protection, pay taxes of neighbours, supply of food for children and etc. In recent years cash Waqf in many Islamic societies is more common and some of the Muslim capitalists, give specific funds in cash as loan to applicants in return the loans will be use for social services for vulnerable strata (Cizakca, 1995).

In the Islamic Republic of Iran in parallel with other Islamic countries there are many examples of benefices and properties' that are allocated for public affairs and we can certainly claimed that the friendly tradition of Waqf has been able to assistant deprived of the vulnerable society. Social entrepreneurship culture in Iran, has managed the value of friendship, divine revelation and seeking Islam to mingle. The Islamic believe inspired act of good and solidify humanitarian consent to God and development prosperity of country. Best instance of well-meaning is to building hundred thousand classrooms and dedicate it's for educational activities. According to official statistics of the school well-meaning in country, extensive participation in school building have belonged to them and, they have taken a heavy labour from the government and ministry of education, all in all 33 percent of the country's schools have been constructed by school well-meaning (Kyhan newspaper, 2006).

Construction, utilization and management of hospitals and clinics on Charitable Contributions by the well-meaning and dedicating them to the needed and deserved patients and free medical services or the low tax in comparison with the private sector hospitals is another example of charity culture and tradition, among the Iranian Muslims. For example, the specialized Razavi hospital of Mashhad is prominent symbol of benevolent will and inspired by the lessons of Islamic school in support of human dignity in the finest and most tangible kind of way which is Waqf (Specialized Razavi hospital of Mashhad, 2008). By promotion of culture of Ehsan, charity, and wake friendly tradition of Waqf, it can be suited part of education needs, health and welfare of the 
vulnerable society and meet the growth and social development in country.

The considerable point in usage of Waqf in development and social welfare is that the Waqf lonely and without commercial and state participation cannot effect considerably on social development. The major benefices and property of dedicated belongs capitalists of the real and legal, private sector and high-income families will be allocated it to activities of public works and charity Profit of private sector in vast increases the share of household income in parallel with the religious belief, can share voluntary Participation such as dedicated and charitable contributions. In addition government can make the tax exemptions granted to benefices, facilities and other policies for encouraging people to participate in the Construction process, so provides development of the country. It can ease Waqf laws and regulations management and benefices in the form of organizations and charity institutions that uses the capacities of the participation of the well-meaning and volunteer groups for the development and welfare. The three-dimensional shape of government, private sector based on the Islamic capitalist and charities and voluntary part have had comprehensive effects on global economic and spiritual a development in Islamic societies. In multi- dimensional models of development, Waqf is one of the significant Islamic activities with characteristics of piety and provides kind of friendship and social justice for promotion of innovation and entrepreneurship dynamism and social development (Brown \& Holloway, 2007).

\section{Conclusion}

This article has tried to show the significance of Waqf to use it in developmental fields. Islamic countries objective experiences have shown that Waqf has been able in distribution of wealth in society and using finance and property in the line with well-meaning humanitarian to develop opportunities and access vulnerable to the main infrastructure development. In Islamic culture, Waqf is as one of the successful entrepreneurship patterns or permanent Islamic almshouses that require using simultaneously business skills and entrepreneurial innovation and using the profits for eliminating poverty and social welfare strata. In addition, by developing the Waqf and charity activities, benevolence, and prosperity in parallel with the private and, the expenses of the transitional government will be reduce. And major needs of the society in the field of education and training fields, higher education, health and treatment that are heavy burden for the government can be done by NGOs and people which will foster the movement cycle of development in parallel with development in public and private sector.

\section{References}

Alioune, N. (2007). Islamic charities in switzerland and the practice of zakat. [Online] Available: www.se1.isn.ch/serviceengine/FileContent?...\&lng=en.

Alvord, S. H., Brown, L. D., \& Letts, C. W. (2004). Social entrepreneurship and societal transformation. The Journal of Applied Behavioural Science, 40(3), 260-282.

Anjavi nejad, S. M., \& Emami, M. (2004). Changes in legislation and principles of Waqf to the new creation. Modares Human Sciences, 8(3).

Arif, M. (1991). The Islamic Voluntary Sector in Southeast Asia. Institute of Southeast Asian Studies, Singapore,.J.KAU: Islamic Econ., 8.

Astan ghods Razavi. (2008). what is Waqf? The portal of Astan Ghods Razavi, [Online] Available: http://www.aqrazavi.org.

Austin, J., Stevenson, Howard \& Wei-Skillern, J. (2006). Social and Commercial Entrepreneurship: Same Differentor Both? Entrepreneurship Theory and Practice, Blackwell Publishing Limited.

Bandarchi, M. (2008). Waqf from the historical and Pseudoxantoma perspective. Mizan monthly, 67.

Bekkers, R. Wiepking, Pamala. (2007). Generosity and Philanthropy: A Literature Review. [Online] Available: www.fss.uu.nl/soc/homes/bekkers/generosity.pdf.

Berger, I. E. (2006). The Influence of Religion on Philanthropy in Canada. School of Business Management, Ryerson University, 350 Victoria Street, Toronto, Ontario, Canada, M5B.

Bremer, J. (2004). Islamic Philanthropy: Reviving Traditional Forms for Building Social Justice. CSID Fifth Annual Conference, Defining and Establishing Justice in Muslim Societies, Washington, DC - May 28-29, [Online] Available: islam-emocracy.org/documents/pdf/2004_Annual_Conference_Program.

Brown, R., \& Holloway, R. (2006). Islamic Philanthropy and the Evolution of Social Entrepreneurship in South East Asia. [Online] Available: www.rhul.ac.uk/management/News-andEvents/seminars/Islamic_Philanthropy_Abstract_nov07.pdf. 
Cizakca, M. (1995). Cash Waqfs of Bursa. Journal of Economic and Social History of the Orient, 38(3), $1555-1823$.

Dees, J., Gregory, J. E., \& Peter. E. (2001). Enterprising Nonprofits: A Toolkit for Social Entrepreneurs. New York: John Wiley \& Sons, Inc.,

Gliedt, T., \& Parker, P. (2007). Green Community Entrepreneurship: Creative Destruction in the Social Economy. International Journal of Social Economics, 34(8), 538-553.

Interview with the head of the school well-meaning of the country, according to the Kayhan newspaper. The historian, 25/2/2006.

Jennifer. (2004). Islamic Philanthropy: Reviving Traditional Forms for Building Social Justice. CSID Fifth Annual Conference, Defining and Establishing Justice in Muslim Societies" Washington, DC - May 28-29, [Online] Available: www.islam-democracy.org/documents/pdf/2004_Annual_Conference_Program.

Kahf, M. (2002). Waqf and its Socio Political Aspects. [Online] Available: www.awqafsa.org.za/.../Waqf\%20\&\%20its\%20Socio\%20Political\%20Aspects\%20-\%20Monzer\%20Kahf.pdf.

Khan, M. F. (1997). Social Dimensions of Islamic Banks in Theory and Practice. Islamic Research and Training Institute, Islamic Development Bank Manuscript. Training Institute, Seminar Proceedings, 23.

Krafess, J. (2005). The influence of the Muslim religion in humanitarian aid. International Review of the Red Cross, 87(858), 327-342.

Kuran, T. (2001). The Provision of public goods under islamic law: origins, impact, and imitations of the Waqf system. Law \& Society Review, 35(4), 841-897.

Miri, A. (2006). Social Entrepreneurship: a review of the political and social field. Knowledge management, 19(72).

Sadeq, A. M. (2002). Waqf, perpetual charity and poverty alleviation. International Journal of Social Economics, 29(1/2), 135-151.

Sakhori, A. (2007). Theoretical and experimental study of humanitarian action. Quarterly Domestic Policy, 1(2).

Salamon, L. M., \& Anheier, H. K. (1997). The Third World's Third Sector in Comparative Perspective. The Johns Hopkins University Institute for Policy Studies, All Rights Reserved [Online] Available: www.undp.org.sa/pages/news/2007/HDR_07/Useful_Docs/En_Country_FactSheet.pdf.

Sami, H. (2006). Muslim Philanthropy and ${ }_{t h}$ Social Security: Prospects, Practices, and Pitfalls. University of Technology, Sydney. Paper presented at the 6 ISTR Biennial Conference held in Bangkok, 9-12.

Seelos, C., \& Johanna, M. (2005). Social Entrepreneurship: Creating New Business Models to Serve The Poor. Business Horizons, 48, 241-246.

The specialized hospital Razavi [Online] Available: http://www.razavihospital.com

Wang, L., \& Graddy, E. (2008). Social Capital, Volunteering, and Charitable Giving. Voluntas.

Weerawardena, J. (2006). Investigating Social Entrepreneurship: A Multidimensional Model. Journal of World Business, 41(1), 21-35. 


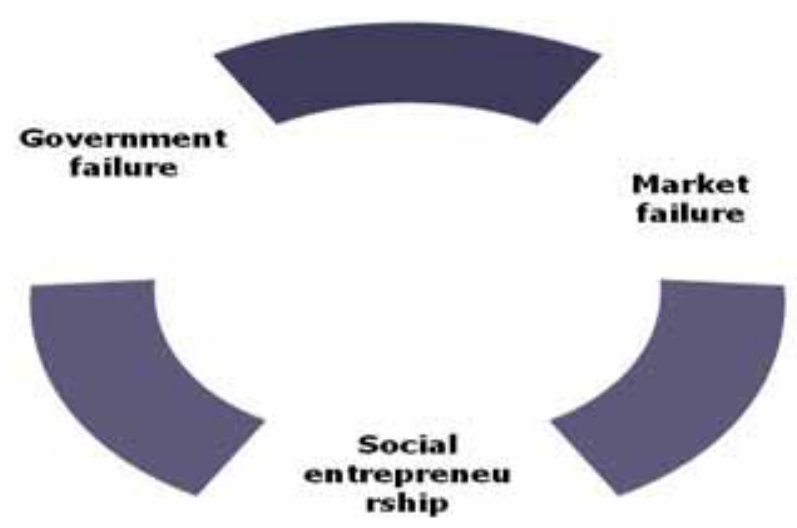

Figure 1. Social entrepreneurship; complement the government and market (Weerawardena, 2006).

\begin{tabular}{|l|l|}
\hline $\begin{array}{l}\text { The works and social } \\
\text { consequences }\end{array}$ & Dedication process \\
\hline $\begin{array}{l}\text { Public works } \\
\text { University }\end{array}$ & \multicolumn{1}{c|}{$\begin{array}{l}\text { Factors determining the } \\
\text { charity Motivators }\end{array}$} \\
\hline $\begin{array}{l}\text { Charity } \\
\text { educational }\end{array}$ & $\begin{array}{l}\text { Religious beliefs: } \\
\text {-Virtue-strong faith-paths of } \\
\text { religious beliefs: } \\
\text {-Virtue-strong } \\
\text { revelation }\end{array}$ \\
\hline \begin{tabular}{l} 
Charity hospital faith-divine \\
\hline institutions
\end{tabular} \\
\hline Library
\end{tabular}

Figure 2. The founder of the good work to solidify and Waqf (derived from the studies conducted by researchers) (Sami, 2006; Krafess, 2005; Jennifer, 2004) 